\title{
Boar semen quality of the Přeštice black-pied breed
} (Short Communication)

\author{
Soňa Frydrychová, Alena Lustyková, Jan Lipenský and Miroslav Rozkot
}

Department of Pig Breeding, Institute of Animal Science, Prague-Uhříněves, Workplace Kostelec nad Orlicí, Czech Republic

\begin{abstract}
The objective of this study was to examine semen quality parameters for the Preštice black-pied breed over a test period of 8 years while considering the potential effects of collection month and boar age. Ninety-nine ejaculates were collected using the gloved-hand technique from healthy and fertile mature boars from selected farms. Ejaculate volumes were relatively low because the boars were accustomed to natural mating. Sperm motility, sperm concentration, percentage of morphologically abnormal spermatozoa (MAS), and sperm motility after $24 \mathrm{~h}$ of storage in Androhep extender (dilution rate 1:1.5) were assessed. Significant differences were found in sperm concentration and MAS rate in relation to collection months and boar age in the monitored years $(P<0.05)$. A tendency for MAS to increase with monitored years was observed. Significant differences in sperm motility and motility after $24 \mathrm{~h}$ of storage were only observed in relation to collection months $(P<0.05)$. Results of this study detected effects due to collection month and boar age on boar semen quality during the monitored years.
\end{abstract}

Keywords: boar, sperm quality parameters, Přeštice black-pied pig

\section{Zusammmenfassung}

Qualität des Eberspermas des Prešticer Schwarzbunten Schweins (Kurzmitteilung)

Ziel dieser Studie war es, die Spermaqualität von Ebern des Prešticer Schwarzbunten Schweins über einen Zeitraum von acht Jahren zu analysieren. Neunundneunzig Ejakulate wurden mittels Handschuhtechnik von gesunden und fruchtbaren Ebern gewonnen. Das Ejakulatvolumen war relativ gering, weil die Eber an natürliche Paarung gewohnt waren. Bewertet wurden die Beweglichkeit der Spermien, die Spermakonzentration und der Prozentsatz der morphologisch abnormalen Spermatozoen (MAS) sowie die Beweglichkeit der Spermien nach 24 Stunden im Spermaverdünner Androhep (Verdünnung 1:1.5). Im Beobachtungszeitraum wurden signifikante Unterschiede $(P<0.05)$ in der Spermakonzentration und im MAS-Anteil in Beziehung zu den Entnahmemonaten und dem Eberalter festgestellt. In laufe der Jahre wurde eine steigende Zahl von MAS im Ebersperma des Prešticer Schwarzbunten Schweins beobachtet. Signifikante Unterschiede $(P<0.05)$ bei der Beweglichkeit der Spermien und der Beweglichkeit der Spermien nach 24 Stunden wurden nur in Beziehung zu den Entnahmemonaten beobachtet.

Die Studie zeigt, dass im Beobachtungszeitraum die Spermaqualität vom Entnahmemonat und dem Eberalter beeinflusst wurde. 
Schlüsselwörter: Eber, Qualität des Spermas, Prešticer Schwarzbuntes Schwein

\section{Introduction}

Reproduction plays a key role in the successful production of farm animals (Omelka et al. 2006). It is important to monitor the quality of fresh boar semen prior to its preservation because the quality of thawed semen depends upon the quality of the original, fresh semen. Tardif et al. (1999) pointed out that monitoring of semen quality is the first step towards improving pig fertility.

In the Czech Republic the Přštice black-pied pig was included in 1992 into the programme for maintaining livestock genetic resources. Because their populations are less influenced by intensive selection in comparison to commercial hybrid lines, farm animals represent a very interesting area for research. The Přštice black-pied pig is our national breed and probably originates from crossing of the Old-Bohemian Bristled pig and the Bavarian pig breed in Western Bohemia (in the area of Přštice, Klatovy \& Domažlice) during the second half of the 19th century. The importance of this breed lies in its genes that provide excellent reproduction performance, adaptability, rather easy care, good vitality, and resistance to diseases (Lustyková et al. 2008) This breed's disadvantages include relatively high back-fat thickness, lower percentage of lean muscle, and poorer feed conversion. It was recognized as a distinct breed in 1964, and since 1996 it has been bred in a closed population. Within that population, genetic markers in association with reproduction traits (Horák et al. 2004, Horák et al. 2005) and gene polymorphisms associated with meat performance traits (Zrůstová et al. 2009) have been studied, but until recently semen quality had not been evaluated. Therefore, the objective of this study, conducted over a test period from 2001 to 2009, was to examine the semen quality parameters of the Preštice black-pied breed while taking into account the potential effects of collection month and boar age.

\section{Material and methods}

Ninety-nine ejaculates were obtained from boars of the Přšstice black-pied breed from 8 months to 5 years of age over a period of 8 years (2001-2009) on selected farms in the Czech Republic. Ejaculates were collected using the gloved-hand technique from healthy and fertile mature boars. Ejaculate volumes were relatively low because the boars were accustomed to natural mating. The gel portion was removed using double gauze. Semen volume and sperm motility were evaluated in the fresh boar semen. The volume of the sperm-rich fraction of the ejaculate was determined using a graduated cylinder. Sperm motility was assessed subjectively using phase contrast microscopy with a heating stage $\left(38^{\circ} \mathrm{C}\right)$ at $100 \times$ magnification. A part of the fresh semen was taken to determine sperm concentration and spermatozoa morphology. The remaining semen was diluted using Androhep extender (Minitüb, Germany) at a semen:extender dilution ratio of 1:1.5 and samples were stored at the temperature of $17^{\circ} \mathrm{C}$ until delivered to the laboratory for cryopreservation. The sperm concentration was determined by a cytometric method using a Bürker's chamber. Morphologically abnormal spermatozoa (MAS) were assessed according to the staining method of Čeřovský (1976). Sperm motility was evaluated $24 \mathrm{~h}$ after semen dilution. Boars 
were divided by age into the following groups: less than 1 year, 1-2 years, 2-3 years, and more than 3 years.

Standard statistical parameters, including arithmetic mean, standard deviation, coefficient of variation, and significance $(P)$ were calculated using the QC Expert program (TriloByte Statistical Software, s.r.o., Pardubice, Czech Republic). Statistical significance was determined using analysis of variance ANOVA at significance levels of $P<0.05$ and $P<0.01$.

\section{Results and discussion}

The overall quality of boars semen included into this study can be characterized as follows (mean \pm SD): semen volume $196.12 \pm 68.85 \mathrm{ml}$, sperm motility $78.79 \pm 9.90 \%$, sperm concentration $472.39 \pm 200.19 \times 10^{3} / \mathrm{mm}^{3}$, MAS $23.20 \pm 20.53 \%$, and sperm motility after $24 \mathrm{~h}$ of storage $69.14 \pm 11.74 \%$ (Table 1 ). The semen quality showed considerable variability. The highest coefficient of variation was detected in the proportion of MAS (88.49\%) and sperm concentration (42.38\%). Very low coefficients of variation were observed in sperm motility $(12.57 \%)$ and sperm motility after $24 \mathrm{~h}$ of storage (16.98\%). The values for semen volume were relatively lower in this study than would be normal in reality because most of the boars were accustomed to natural mating. Therefore, semen volume was not evaluated statistically. Kuciel et al. (1980) had studied phenotypic variability in the characteristics of ejaculates from boars of various breeds for 1 year from age 12 to 24 months and reported for the Přeštice black-pied breed values for sperm motility of $67.33 \%$, motility after $24 \mathrm{~h}$ of $60.67 \%$, and MAS of $7.01 \%$. Mašek et al. (1979) had pointed out that this breed had the highest volume compared to other breeds and reported sperm concentration was $338.53 \times 10^{3} / \mathrm{mm}^{3}$. The semen quality measures for the Přeštice black-pied breed by years is presented in Table 1.

Table 1

Boar semen quality parameters according to years

\begin{tabular}{|c|c|c|c|c|c|c|c|c|c|c|c|}
\hline \multirow[t]{2}{*}{ Year } & \multirow[t]{2}{*}{$\mathrm{n}$} & \multicolumn{2}{|c|}{$\begin{array}{c}\text { Semen } \\
\text { volume, } \mathrm{ml}\end{array}$} & \multicolumn{2}{|c|}{$\begin{array}{c}\text { Sperm } \\
\text { motility, \% }\end{array}$} & \multicolumn{2}{|c|}{$\begin{array}{c}\text { Sperm concentration, } \\
10^{3} / \mathrm{mm}^{3}\end{array}$} & \multicolumn{2}{|c|}{$\begin{array}{l}\text { MAS, } \\
\%\end{array}$} & \multicolumn{2}{|c|}{$\begin{array}{c}\text { Sperm motility } \\
24 \mathrm{~h}, \%\end{array}$} \\
\hline & & Mean & SD & Mean & SD & Mean & SD & Mean & SD & Mean & SD \\
\hline 2001 & 8 & 275.63 & 49.09 & 77.50 & 7.07 & 497.50 & 145.68 & $16.00^{\mathrm{a}}$ & 7.32 & 68.75 & 9.54 \\
\hline 2002 & 19 & 170.84 & 81.25 & 76.05 & 19.33 & 479.84 & 121.58 & $12.29^{\mathrm{c}, \mathrm{e}}$ & 15.00 & 68.16 & 19.52 \\
\hline 2003 & 11 & 196.82 & 55.33 & 79.09 & 5.84 & 521.06 & 199.80 & 23.82 & 17.52 & 69.55 & 8.20 \\
\hline 2004 & 10 & 180.00 & 44.72 & 81.00 & 4.59 & $557.20^{\mathrm{a}}$ & 232.76 & 20.95 & 16.42 & 69.50 & 4.97 \\
\hline 2005 & 13 & 173.08 & 48.54 & 78.85 & 4.63 & 496.58 & 243.89 & 22.08 & 18.90 & 71.92 & 5.22 \\
\hline 2006 & 7 & 175.71 & 16.18 & 82.14 & 3.93 & $342.50^{b}$ & 65.44 & 25.21 & 30.04 & 66.43 & 20.76 \\
\hline 2007 & 5 & 218.00 & 65.35 & 81.00 & 4.18 & 423.50 & 193.03 & 23.00 & 31.11 & 68.00 & 7.58 \\
\hline 2008 & 7 & 203.57 & 106.29 & 76.43 & 6.90 & 427.14 & 294.50 & $32.93^{d}$ & 18.98 & 64.29 & 9.76 \\
\hline 2009 & 19 & 210.79 & 68.11 & 79.74 & 7.16 & 442.37 & 211.50 & $34.47^{b, f}$ & 23.35 & 71.05 & 7.37 \\
\hline Total & 99 & 196.12 & 68.85 & 78.79 & 9.90 & 472.39 & 200.19 & 23.20 & 20.53 & 69.14 & 11.74 \\
\hline
\end{tabular}

MAS: morphologically abnormal spermatozoa, a,b,c,d $p<0.05, \quad$ e,f $p<0.01$

Significant differences in sperm concentration and MAS were found between years. Sperm concentration was different in 2004 and 2006 ( $557.20 \pm 232.76$ vs. $342.50 \pm 65.44 \times 10^{3} / \mathrm{mm}^{3}$; $P<0.05)$. Differences in MAS were observed between years 2001 vs. 2009, 2002 vs. 2008 $(P<0.05)$, and 2002 vs. $2009(P<0.01)$. An increasing tendency in MAS was observed with the 
passage of monitored years (from $16 \%$ to $34.5 \%$ ). Sperm motility and sperm motility after $24 \mathrm{~h}$ of storage were relatively constant throughout the individual years and no significant differences were found.

The mean values of sperm motility, sperm concentration, MAS and sperm motility after $24 \mathrm{~h}$ of storage are presented by calendar month of collection in Table 2.

Table 2

Effect of month on quality of boar semen

\begin{tabular}{|c|c|c|c|c|c|c|c|c|c|c|c|}
\hline \multirow[t]{2}{*}{ Month } & \multirow[t]{2}{*}{$\mathrm{n}$} & \multicolumn{2}{|c|}{$\begin{array}{c}\text { Semen } \\
\text { volume, ml }\end{array}$} & \multicolumn{2}{|c|}{$\begin{array}{c}\text { Sperm } \\
\text { motility, \% }\end{array}$} & \multicolumn{2}{|c|}{$\begin{array}{c}\text { Sperm concentration, } \\
10^{3} / \mathrm{mm}^{3}\end{array}$} & \multicolumn{2}{|c|}{$\begin{array}{c}\text { MAS, } \\
\%\end{array}$} & \multicolumn{2}{|c|}{$\begin{array}{c}\text { Sperm motility } \\
24 \mathrm{~h}, \%\end{array}$} \\
\hline & & Mean & SD & Mean & SD & Mean & SD & Mean & SD & Mean & $\mathrm{SD}$ \\
\hline & 4 & 5.00 & 0.91 & 00.00 & 9.13 & & & $23.38^{c}$ & 28.15 & & 9.4 \\
\hline February & 1 & 149.43 & 50.82 & $69.29^{a}$ & 31.42 & 518.57 & 136 & $7.21^{\mathrm{a}, \mathrm{e}}$ & 2.66 & $55.71^{\mathrm{a}, \mathrm{e}}$ & 27.60 \\
\hline March & & 177.00 & 44.42 & $81.00^{b}$ & 4.59 & $422.80^{\mathrm{a}}$ & & $18.75^{\mathrm{e}}$ & 14.74 & $72.00^{f}$ & 5.87 \\
\hline A mrit & 12 & 205.00 & 88.98 & & 3.02 & $385.67^{e, c}$ & & & 13.60 & & 6.2 \\
\hline May & 15 & 190.67 & & & 5.30 & $454.07^{a}$ & & & 25.08 & & 14.3 \\
\hline & 7 & 137.14 & 43.86 & & 4.88 & & & & 8.17 & & 4.8 \\
\hline July & $\varepsilon$ & & 5 & & 3.78 & & 1 & 24 & 18.01 & $0^{\mathrm{b}}$ & 5.3 \\
\hline Augu & & 199.06 & 70.29 & 77.19 & 6.05 & $478.59^{a}$ & 276 & $30.34^{b}$ & 23.74 & $68.75^{b}$ & 8.6 \\
\hline & 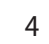 & 165.00 & 38.73 & 77.50 & 6.45 & $711.25^{b, f}$ & & 27.25 & 25.52 & 66.25 & 11.09 \\
\hline October & 3 & & & & 10.41 & 448.33 & & $54.83^{d, f}$ & & 65.00 & 13.2 \\
\hline & 1 & 282.50 & 62.38 & 81.25 & 4.79 & $337.50^{\mathrm{e}}$ & 109.96 & $37.63^{b}$ & 30.21 & 70.00 & 8.1 \\
\hline December & 9 & 280.56 & 48.25 & 76.67 & 7.07 & $463.06^{a}$ & 171.02 & $17.11^{\mathrm{e}}$ & 7.61 & $67.78^{b}$ & 9.3 \\
\hline
\end{tabular}

MAS: morphologically abnormal spermatozoa, $a, b, c, d P<0.05, \quad$ e, $f P<0.01$

The lowest motility value was in February, and motility values were highest in March to July $(P<0.05)$. This is in contrast with the findings of Wolf \& Smital (2009), who had observed sperm motility to be relatively constant throughout the year. The percentage of sperm motility after $24 \mathrm{~h}$ of storage was lowest in February (55.71 $\pm 27.60 \%)$ vs. January, May, July, October, December $(P<0.05)$, March, April, and June $(P<0.01)$. Statistically significant differences in sperm concentration were noted in March, May, August and December vs. September; in April vs. July $(P<0.05)$; and in April and November vs. September $(P<0.01)$. The highest value for sperm concentration was determined in September, at $711.25 \times 10^{3} / \mathrm{mm}^{3}$. Wolf \& Smital (2009) had noted that sperm concentration was highest in winter and early spring (December to April) and lowest in late summer and early autumn (August to October). The MAS percentage was higher from August to November and the value was lowest in February (7.21 $2.66 \%$ ). This could have been caused by variation of temperature in the summer and in the autumn season. Several studies have shown that photoperiod (Anderson et al. 1998, Sancho et al. 2004), elevated ambient temperature, heat stress and/or hot weather have averse effects on semen production (Mauget et al. 1987, Colenbrander et al. 1993, Frydrychová et al. 2007, Wolf \& Smital 2009) as well as semen quality (Larrson et al. 1984, Sonderman et al. 2008) in boars, and especially an increased proportion of MAS (Wettemann et al. 1976, Cameron et al. 1980). On the other hand, this could also have been an influence of the genetic background (Čeřovský et al. 2005). Falkenberg et al. (1994) had recorded a positive correlation between the percentage of normal spermatozoa in semen and number of piglets born in litters. Kawecka et al. (2008) also found a negative correlation between MAS rate (especially in relation to the 
proximal droplet) and other ejaculate quality traits $(P<0.05)$. We also observed a negative correlation between MAS rate and sperm motility ( $r=-0.40, P<0.05)$, sperm concentration $(\mathrm{r}=-0.35, P<0.05)$ and sperm motility after $24 \mathrm{~h}(\mathrm{r}=-0.43, P<0.05)$. Colenbrander \& Kemp (1990) had indicated that sperm production of boars may fluctuate by as much as 25 to $30 \%$ throughout the year.

The dependence of semen quality parameters on boar age are summarized in Table 3.

Table 3

Boar semen quality parameters according to age

\begin{tabular}{|c|c|c|c|c|c|c|c|c|c|c|c|}
\hline \multirow[t]{2}{*}{ Year } & \multirow[t]{2}{*}{$n$} & \multicolumn{2}{|c|}{$\begin{array}{l}\text { Semen volume, } \\
\mathrm{ml}\end{array}$} & \multicolumn{2}{|c|}{$\begin{array}{c}\text { Sperm motility, } \\
\%\end{array}$} & \multicolumn{2}{|c|}{$\begin{array}{l}\text { Sperm concentration, } \\
\qquad 10^{3} / \mathrm{mm}^{3}\end{array}$} & \multicolumn{2}{|c|}{$\begin{array}{l}\text { MAS, } \\
\%\end{array}$} & \multicolumn{2}{|c|}{$\begin{array}{c}\text { Sperm motility } \\
24 \mathrm{~h}, \%\end{array}$} \\
\hline & & Mean & SD & Mean & SD & Mean & SD & Mean & SD & Mean & SD \\
\hline & 17 & 150.59 & J & 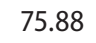 & 2 & 483.18 & 17302 & 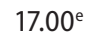 & 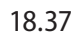 & 2 & 18.67 \\
\hline-2 & 44 & & 5 & 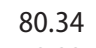 & & & & fe & 16 & 0 & 8.76 \\
\hline - & 21 & & 82. & & & & & $23.95^{\mathrm{a}}$ & 22 & & 8.56 \\
\hline$>3$ & 11 & 274.27 & 67.21 & 78.82 & 6.43 & $401.82^{\mathrm{b}}$ & 225.93 & $38.64^{b, f}$ & 19.47 & 68.64 & 6.36 \\
\hline
\end{tabular}

MAS: morphologically abnormal spermatozoa, a,b $P<0.05, \quad$ e,f $P<0.01$

Significant differences were determined in sperm concentration and rate of MAS. Sperm concentration differed at age $2-3$ years vs. $>3$ years $\left(551.17 \pm 208.18\right.$ vs. $401.82 \pm 225.93 \times 10^{3}$ / $\left.\mathrm{mm}^{3} ; P<0.05\right)$. According to the results of Wolf \& Smital (2009), sperm concentration increased sharply up to 11 months of age, followed by a long-term moderate decrease until 3 years of age and stabilization thereafter. Differences in the MAS rate were found between ages $<1$ years and $1-2$ years vs. $>3$ years $(P<0.01)$, as well as for $2-3$ years vs. $>3$ years $(P<0.05)$. Wolf $\&$ Smital (2009) had reported that percentage of abnormal sperm increased over the entire productive lifetime of the boar. No significant differences were found in sperm motility and sperm motility after $24 \mathrm{~h}$ of storage in relation to boar age. Wolf \& Smital (2009) had noted that motility was reduced with age. Jankeviciute \& Zilinskas (2002) had observed significant impacts of age on volume, spermatozoa concentration and sperm morphology $(P<0.05)$.

In conclusion, the present findings show effects in relation to collection month and boar age on semen quality parameters for the Přeštice black-pied breed during 2001-2009. This experiment suggests the possibility for utilizing boars as genetic resources for collection at age 2-3 years for the sake of highest sperm concentration and optimal rate of MAS. The findings show the best period for collection as measured by semen quality parameters to be from January to July, except for February. We also observed an overall increase of MAS in boar semen through the monitored years.

\section{Acknowledgements}

This study was supported by research project MZE0002701404 from the Ministry of Agriculture of the Czech Republic. 


\section{References}

Anderson H, Wallgren M, Rydhmer L, Lundström K, Anderson K, Forsberg M (1998) Photoperiodic effects on pubertal maturation of spermatogenesis, pituitary responsiveness to exogenous $\mathrm{GnRH}$, and expression of boar taint in crossbred boars. Anim Reprod Sci 54, 121-137

Cameron RD, Blackshow AW (1980) The effect of elevated ambient temperature on spermatogenesis in the boar. J Reprod Fertil 59, 173-179

Colenbrander B, Feitsma H, Grooten HJ (1993) Optimizing semen production for artificial insemination in swine. J Reprod Fertil Suppl 48, 207-215

Colenbrander B, Kemp B (1990) Factors influencing semen quality in pigs. J Reprod Fertil Suppl 40, 105-115

Čeřovský J, Frydrychová S, Lustyková A, Rozkot M (2005) Changes in boar semen with a high and low level of morphologically abnormal spermatozoa. Czech J Anim Sci 50, 289-299

Falkenberg H, Ritter E (1994) Relations between morphological and biochemical sperm characteristics in boars and farrowing performance in sows. Arch Tierz 37, 287-300 [in German]

Frydrychová S, Lustyková A, Čeřovský J, Lipenský J, Rozkot M (2007) Seasonal changes of boar semen production. Res Pig Breed 1, 31-33

Horák P, Urban T, Dvořák J (2004) Genetic variability of the CRC and MYF4 genes in genetic resource, Přeštice Black-Pied pig. Arch Tierz 47, 231-238

Horák P, Urban T, Dvorák J (2005) The FUT1 and ESR genes - their variability and associations with reproduction in Přšštice Black-Pied sows. J Anim Breed Genet 122, 210-213

Jankeviciute N, Zilinskas H (2002) Influence of some factors on semen quality of different breeds of boars. Vet Med Zoot 19, 15-19

Kawecka M, Pietruszka A, Jacyno E, Czarnecki R, Kamyczek M (2008) Quality of semen of young boars of the breeds Pietrain and Duroc and their reciprocal crosses. Arch Tierz 51, 42-54

Kuciel J, Mašek N, Pospíchal J, Muzikantová J (1980) Genetic analysis of the criterional parameters of the motility, survival and morphological changes of boar spermatozoa. Živ Výr 25, 911-920 [in Czech]

Larsson K, Einarsson S (1984) Seminal changes in boars after heat stress. Acta Vet Scand 25, 57-66

Lustyková A, Frydrychová S, Lipenský J, Vejnar J, Rozkot M (2008) Practical aspects of porcine semen collection for conservation and utilization of farm animal genetic resources. Res Pig Breed 2, 22-25

Mašek N, Kuciel L, Pospíchal L (1979) Genetic analysis of the volume of filtrated ejaculate and sperm concentration in boars used for insemination. Živ Výr 24, 37-46 [in Czech]

Mauget R, Boissin J (1987) Seasonal changes in testis weight and testosterone concentration in the European wild boar (Sus scrofa, L.) Anim Reprod Sci 13, 67-74

Omelka R, Peškovičková D, Martiniakova M, Bauer M, Bauerova M (2006) Effect of the estrogen receptor (ESR) and ryanodine receptor (RYR1) genes on reproductive traits of Slovak Large White, White Meaty and Landrace pigs. Arch Tierz 49, 357-362

Sancho S, Pinart E, Briz M, Garcia-Gil N, Badia E, Bassols J, Kádár E, Pruneda A, Bussalleu E, Yeste M, Coll MG, Bonet S (2004) Semen quality of postpubertal boars during increasing and decreasing natural photoperiods. Theriogenology 62, 1271-1282

Sonderman JP, Luebbe JJ (2008) Semen production and fertility issues related to differences in genetic lines of boars. Theriogenology 70, 1380-1383

Tardif S, Laforest JP, Cormier N, Bailey JL (1999) The importance of porcine sperm parameters on fertility in vivo. Theriogen 52 , 447-459

Wettemann RP, Wells ME, Omstvedt IP, Pope CE, Turman EJ (1976) Influence of elevated ambient temperature on reproductive performance of boars. J Anim Sci 42, 664-669

Wolf J, Smital J (2009) Quantification of factors affecting semen traits in artificial insemination boars from animal model analyse. J Anim Sci 87, 1620-1627 
Zrůstova J, Knoll A, Urban T, Čepica S (2009) The visfatin (NAMPT, PBEF1) gene polymorphisms and associations with meat performance traits in three pig breeds kept in the Czech Republic. Czech J Anim Sci 54, 443-447

Received 23 June 2010, accepted 18 January 2011.

Corresponding author:

Soňa Frydrychová

email: frydrychova.sona@vuzv.cz

Institute of Animal Science, Prague-Uhříněves, Department of Pig Breeding, Workplace Kostelec nad Orlicí, Komenského 1239, 51741 Kostelec nad Orlicí, Czech Republic 